\title{
Microstructural Analysis of Slags using Raman Micro Spectroscope
}

\author{
Su Kyoung Park | In Cheol Kwon* | Su Jeong Lee** | II Kwon Huh*** | Nam Chul Cho' \\ Department of Cultural Heritage Conservation Science, Gongju National University, Gongju-si, 32588, Republic of Korea \\ * Department of Conservation and Art Bank, National Museum of Modern and Contemporary Art, \\ Cheongju, 28501, Republic of Korea \\ **Monitoring team, Chungnam Cultural Heritage Association, Yesan, 32432, Republic of Korea \\ ***Conservation Science Laboratory, Jinju National Museum, Jinju, 52692, Republic of Korea \\ ${ }^{1}$ Corresponding Author: nam1611@kongju.ac.kr, +82-42-850-8541
}

\begin{abstract}
The metal-manufacturing method and smelting temperature of ancient metal-production processes have been studied by analyzing the principal elements and microstructures of slag. However, the microstructure of slag varies according to the solidification cooling rate and types and relative amounts of various oxides contained within the smelting materials. Hence, there is a need for accurate analysis methods that allow slag to be distinguished by more than its composition or microstructure. In this study, the microstructures of slag discharged as a result of smelting iron sands collected from Pohang and Gyeongju, as well as the slag excavated from the Ungyo site in Wanju, were analyzed by using metalloscopy, scanning election microscopy-energy dispersine X-ray spectroscopy(SEM-EDS) and wavelength dispersive X-ray fluorenscence(WD-XRF). Furthermore, the microcrystals were accurately characterized by performing Raman micro-spectroscopy, which is a technique that can be used to identify the microcrystals of slags. SEM-EDS analysis of Pohang slag indicated that its white polygonal crystals could be Magnetite; however, Raman micro-spectroscopy revealed that these crystals were actually ulvöspinel. Raman micro-spectroscopy and SEM-EDS were also used to verify that the coarse white dendritic structures observed in the Gyeongju-slag were Wüstites. Additionally, the Wanju slag was observed to have a glassy matrix, which was confirmed by Raman micro-spectroscopy to be Augite. Thus, we have demonstrated that Raman micro-spectroscopy can accurately identify slag microcrystals, which are otherwise difficult to distinguish as solely based on their chemical composition and crystal morphology. Therefore, we conclude that it has excellent potential as a slag analysis technique.
\end{abstract}

Key Words: Microcrystal characterization, Ancient slag analysis, Microstructure of slags

\section{INTRODUCTION}

Raman micro spectroscope is one type of Raman spectroscope that employs a Raman spectrometer and an optical microscope, and it is capable of analyzing even trace amounts of samples. Raman micro spectroscope can be used to identify the structure of materials using trace amounts of sample material and it is useful for research into cultural heritage materials because it is a nondestructive analysis method(Park et al., 2011).

In country, research has been conducted on the properties of various materials using Raman micro spectroscope for the identification of pigment elements(Lee, 2015) and analys is of corrosive compounds on bronze objects(Park et al., 2011; Lee et al., 2012; Kim and Jeong, 2015). In addition, it has been demonstrated that if the compounds and microstructures can't be determined by scanning electron microscopy-energy dispersive X-ray spectroscopy(SEM-EDS) or wavelength dispersive X-ray fluorenscence(WD-XRF) analyses, which have been used to identify corrosive compounds, Raman spectroscope can be used to analyze them accurately(Lee $e t$ al., 2012; Kim and Jeong, 2015).

Furthermore, in country, ancient metal-production processes have been investigated using various slags excavated from metal-production sites, and the iron manufacturing method and smelting temperature have been studied by analyzing 
the principal elements and microstructures of slags(Kang, 2009; Choi, 2017; Lee, 2017; Bae, 2018). However, the microstructure of slag varies with the types and relative amounts of various oxides contained in the smelting materials, as well as with the cooling rate during solidification. Hence, there is a need for accurate analysis methods to overcome the current limitations of being able to distinguish slag only by its composition or microstructure.

Therefore, in this study, the microstructures of slags discharged from iron smelting processes conducted on iron sands collected from Gyeongju and Pohang and the slags excavated from the Ungyo site in Wanju, Jeollabuk-do (Three Kingdoms Period, AD 3C) were analyzed through SEM-EDS and WD-XRF. In particular, the microcrystals, which are otherwise difficult to distinguish, were accurately characterized by Raman micro spectroscope. The findings presented herein will be useful for identifying the microcrystals of slags and characterizing metal-production sites.

\section{MATERIALS AND METHODS}

\subsection{Samples}

The samples analyzed in this study were slags discharged from smelting processes conducted on iron sands collected from Gyeongju and Pohang and the slags excavated from the Ungyo site in Wanju, Jeollabuk-do(Table 1, Figure 1). The analyzed compositions and microstructures of the slags discharged from the smelting processes conducted on two types of iron sands and the slag excavated from the Ungyo site in Wanju, Jeollabuk-do. In particular, microcrystals that are otherwise difficult to distinguish were accurately identified by Raman micro spectroscopy.

\subsection{Research methods}

\subsubsection{Principal component analysis}

With the powdered samples, the principal component analysis of each sample was conducted using wavelength dispersive X-ray fluorescence spectrometry(S4 Pioneer, Bruker AXS GmbH, Germany). The power was $4 \mathrm{~kW}$, the ATM was Helium, the sample preparation used a liquid cup, and the sample mask was $34 \mathrm{~mm}$.

\subsubsection{Microstructure and chemical composition}

A portion of the sample was obtained by cutting with a diamond grinder, taking care to prevent foreign matter from adhering to it. The specimens were mounted on an epoxy

Table 1. List of sample

\begin{tabular}{ccc}
\hline Sample No. & Sample name & Characteristics \\
\hline No.1 & Pohang-slag & $\begin{array}{r}\text { Iron-slag, smelting processes conducted on iron sands collected from Pohang, } \\
\text { foreign matter adhered to the surface, bright grey slag }\end{array}$ \\
\hline No.2 & Gyeongju-slag & $\begin{array}{c}\text { Iron-slag, smelting processes conducted on iron sands collected from Gampo, } \\
\text { Gyeongju, traces of downward flow are visible, dark grey slag }\end{array}$ \\
\hline No.3 & Wanju-slag & $\begin{array}{c}\text { Copper-slag, excavated from Ungyo site in Wanju, Jeollabuk-do, partial green } \\
\text { corrosion, dark grey slag }\end{array}$ \\
\hline
\end{tabular}

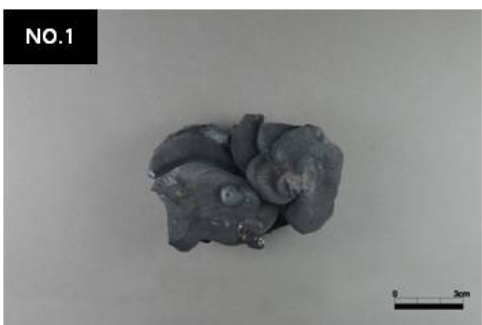

\section{NO.2}

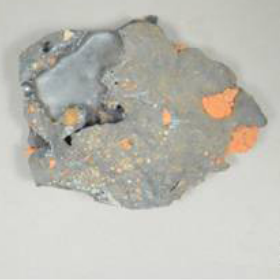

NO.3

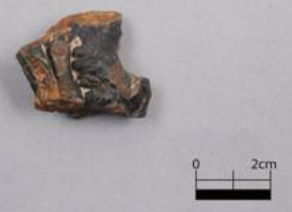

Figure 1. Slag samples. (Left) Smelting processes on iron sands collected from Pohang, (Middle) Smelting processes on iron sands collected from Gyeongju, (Right) Excavated from copper smelting site at Wanju. 
Table 2. List of reference Raman shift

\begin{tabular}{cccc}
\hline \multicolumn{2}{c}{ Chemical formula } & Reference wavenumbers $\left(\mathrm{cm}^{-1}\right)$ & Reference \\
\hline Fayalite & $\mathrm{Fe}_{2} \mathrm{SiO}_{4}$ & $815,835,677,155,173,241,290,384$ & Muralha et al., 2011 \\
\hline Wüstite & $\mathrm{FeO}$ & 652,471 & Demoulin et al., 2010 \\
\hline Ulvöspinel & $\mathrm{Fe}_{2} \mathrm{TiO}_{4}$ & $679,495,561$ & Wang et al., 2004 \\
\hline Magnetite & $\mathrm{Fe}_{3} \mathrm{O}_{4}$ & $\begin{array}{c}667,305,539 \\
(\text { or } 665,293,539)\end{array}$ & Muralha et al., 2011 \\
\hline Augite & $\begin{array}{c}(\mathrm{Ca}, \mathrm{Mg}, \mathrm{Fe}, \mathrm{Ti}, \mathrm{Al})_{2} \\
(\mathrm{Si}, \mathrm{Al})_{2} \mathrm{O}_{6}\end{array}$ & $\begin{array}{c}667,1006,226,299,327,355,392,533, \\
555,707,769,863,928,1043,1102\end{array}$ & Buzatu and Buzgar, 2010 \\
\hline
\end{tabular}

Table 3. WD-XRF results of No.1 Pohang-slag

\begin{tabular}{|c|c|c|c|c|c|c|c|c|c|c|}
\hline \multirow{2}{*}{ Sample } & \multicolumn{10}{|c|}{ Element (wt\%) } \\
\hline & $\mathrm{FeO}$ & $\mathrm{TiO}_{2}$ & $\mathrm{SiO}_{2}$ & $\mathrm{Al}_{2} \mathrm{O}_{3}$ & $\mathrm{CaO}$ & $\mathrm{K}_{2} \mathrm{O}$ & $\mathrm{MgO}$ & $\mathrm{MnO}$ & $\mathrm{P}_{2} \mathrm{O}_{5}$ & $\mathrm{~V}_{2} \mathrm{O}_{5}$ \\
\hline No.1 & 58.19 & 10.98 & 14.91 & 11.15 & 0.89 & 1.44 & 1.42 & 0.79 & 0.23 & - \\
\hline
\end{tabular}

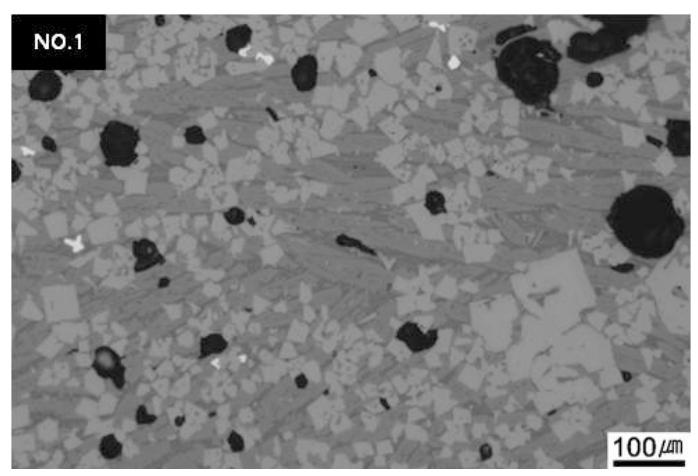

Figure 2. Microstructure of No.1 Pohang-slag $(\times 100)$.

resin, polished sequentially from 220 mesh to 4000 mesh, and then finely polished with $3-\mu \mathrm{m}$ and $1-\mu \mathrm{m}$ DP-Suspension $\mathrm{P}($ Struers, Denmark) . The microstructures of the pretreated samples were observed with a metallurgical microscope (DM-2500M, Leica, Germany). The microstructures and chemical composition of microsites in the microstructures were analyzed by SEM(MIRA3, TESCAN, Czech) and EDS(QUANTA300, BRUKER, Germany). The sample was then coated with platinum to increase its conductivity while minimizing the effect on the composition ratio.

\subsubsection{Raman micro spectroscopy}

Raman micro spectroscope[LabRamARAMIS, Horiba JobinYvon, France (He-Ne laser, $633 \mathrm{~nm}$ )] was conducted to examine the microcrystals of the slags, which were then accurately identified by comparison with reference Raman shifts(Table 2).

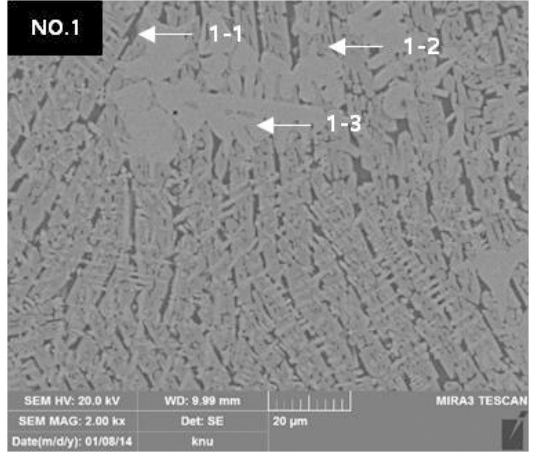

Figure 3. SEM image and points of EDS analysis of No.1 Pohang-slag.

\section{RESULTS AND DISCUSSION}

\subsection{No.1 Pohang-slag}

Table 3 show the WD-XRF results of No.1 Pohang-slag revealed $\mathrm{FeO}(58.19 \mathrm{wt} \%)$ and $\mathrm{TiO}_{2}(10.98 \mathrm{wt} \%)$ and other compounds including $\mathrm{SiO}_{2}, \mathrm{Al}_{2} \mathrm{O}_{3}, \mathrm{CaO}, \mathrm{K}_{2} \mathrm{O}, \mathrm{MgO}, \mathrm{MnO}$ and $\mathrm{P}_{2} \mathrm{O}_{5}$. Metallurgical microscopy images(Figure 2) revealed greyish-white long columnar structures in the background, a glassy matrix, and numerous white polygonal structures. Figure 3 and Table 4 show the SEM-EDS results of Pohang-slag. In Figure 3, 1-1 is a glassy base matrix with high contents of $\mathrm{FeO}$ (26.18 wt\%), $\mathrm{SiO}_{2}\left(29.97 \mathrm{wt} \%\right.$ ) and $\mathrm{Al}_{2} \mathrm{O}_{3}(14.77 \mathrm{wt} \%) ; 1-2$ is a long columnar structure in the background, which appears to 
be Fayalite and has high contents of $\mathrm{FeO}(60.52 \mathrm{wt} \%)$ and $\mathrm{SiO}_{2}$ (15.00 wt $\left.\%\right)$; and 1-3 is a white polygonal structure. In previous studies, the white polygonal crystals observed in such microstructures of slags were mostly identified as Magnetite; however, SEM-EDS results indicated a higher content of $\mathrm{TiO}_{2}$ in these crystals. Hence, Raman micro spectroscope was conducted for more accurate identification. Furthermore, the long columnar structures in the background, which were thought to be Fayalite, were analyzed via
Raman micro spectroscope. From the Raman micro spectroscope for Pohang-slag, Raman shifts of 489 and 680 $\mathrm{cm}^{-1}$ were detected in the white polygonal structure(Figure 4, 5), which coincide with the Raman shifts of Ulvöspinel(Table 2). In the long columnar structure in the background, Raman shifts of 296, 384, 817 , and $841 \mathrm{~cm}^{-1}$ were detected (Figure 6,7), which coincide with the Raman shifts of Fayalite(Table 2).

Table 4. EDS results for No.1 Pohang-slag

\begin{tabular}{|c|c|c|c|c|c|c|c|c|c|c|}
\hline \multirow{2}{*}{ Position } & \multicolumn{10}{|c|}{ Element (wt\%) } \\
\hline & $\mathrm{C}$ & $\mathrm{FeO}$ & $\mathrm{SiO}_{2}$ & $\mathrm{CaO}$ & $\mathrm{Al}_{2} \mathrm{O}_{3}$ & $\mathrm{~K}_{2} \mathrm{O}$ & $\mathrm{TiO}_{2}$ & $\mathrm{MgO}$ & $\mathrm{MnO}$ & $\mathrm{V}_{2} \mathrm{O}_{5}$ \\
\hline $1-1$ & 12.00 & 26.18 & 29.97 & 9.87 & 14.77 & 5.04 & 2.17 & - & - & - \\
\hline $1-2$ & 2.27 & 60.52 & 15.00 & 0.71 & 5.50 & 0.60 & 12.01 & 2.42 & 0.96 & - \\
\hline $1-3$ & 1.56 & 53.54 & 2.87 & - & 6.30 & - & 30.95 & 2.59 & - & 2.29 \\
\hline
\end{tabular}
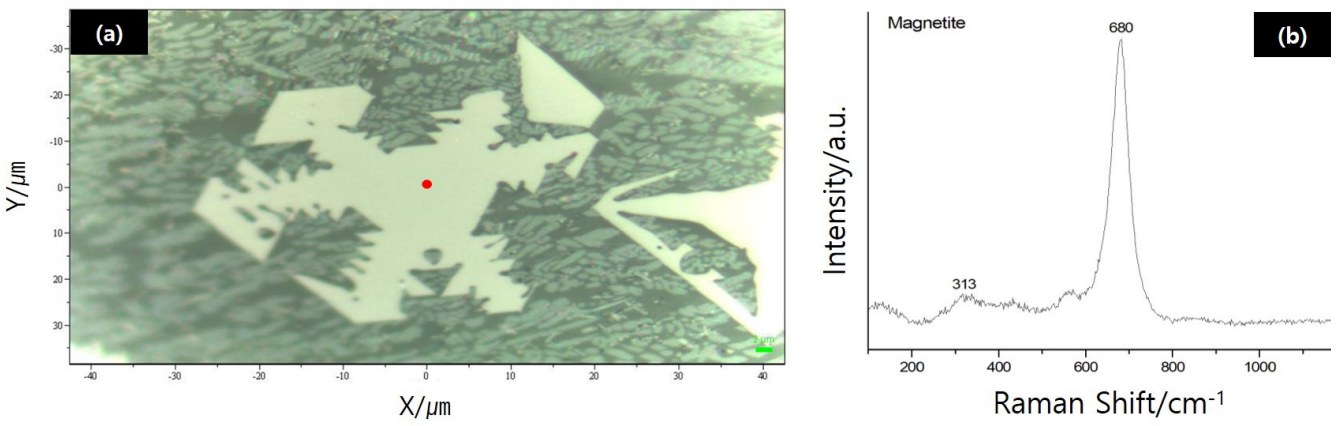

Figure 4. Raman micro spectroscopy results for No.1 Pohang-slag(Magnetite). (a) Image of area in which the spectrum(b) was collected.
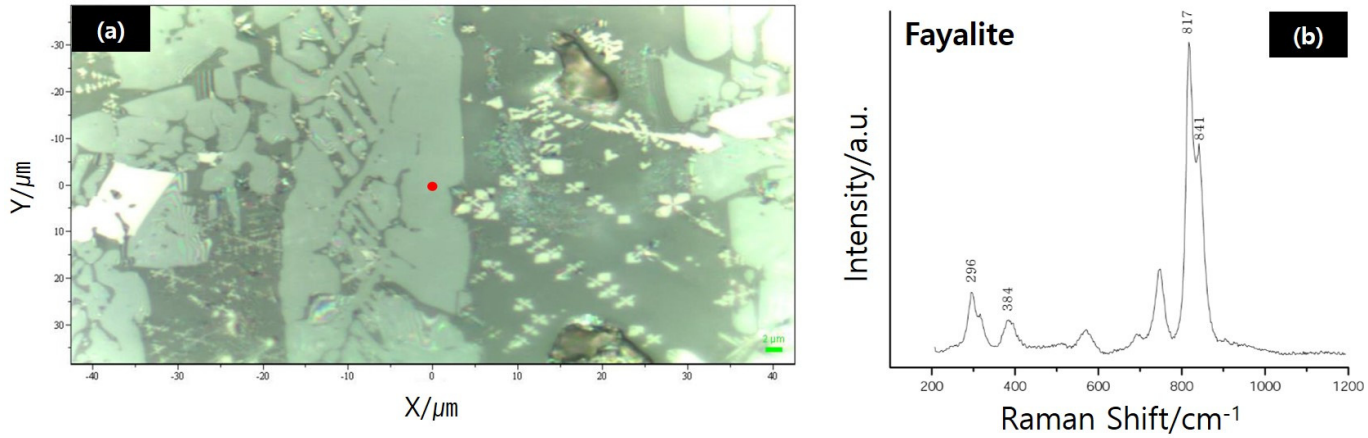

Figure 5. Raman micro spectroscopy results for No.1 Pohang-slag(Ulvöspinel). (a) Image of area in which the spectrum(b) was collected. 


\subsection{No.2 Gyeongju-slag}

Table 5 is WD-XRF analysis of No.2 Gyeongju-slag revealed $\mathrm{FeO}(79.08 \mathrm{wt} \%), \mathrm{TiO}_{2}(0.73 \mathrm{wt} \%)$ and other compounds including $\mathrm{SiO}_{2}, \mathrm{Al}_{2} \mathrm{O}_{3}, \mathrm{CaO}, \mathrm{K}_{2} \mathrm{O}$ and $\mathrm{MnO}$. Metallurgical microscopy images(Figure 6) revealed a broad distribution of greyish-white long columnar structures, with glassy matrices between them. In addition, coarse white dendritic structures were distributed. Figure 7, Table 6 show the SEM-EDS results for No.2 Gyeongju-slag. In Figure 7, 2-1 is a glassy matrix with high contents of $\mathrm{FeO}(51.32 \mathrm{wt} \%), \mathrm{SiO}_{2}(20.81 \mathrm{wt} \%)$ and $\mathrm{Al}_{2} \mathrm{O}_{3}(12.14 \mathrm{wt} \%)$; and 2-2 is a white coarse dendritic structure with $\mathrm{FeO}(98.24$ $w t \%)$ and $\mathrm{TiO}_{2}(1.76 \mathrm{wt} \%)$, which is presumably wüstite. For more accurate identification of the microstructure, Raman micro spectroscope was conducted on No.2 Gyeongju- slag. A Raman shift of $646 \mathrm{~cm}^{-1}$ was detected in the white polygonal structure(Figure 8), which coincides with a Raman shift of Wüstite(Table 2).

\subsection{No.3 Wanju-slag}

Table 7 is WD-XRF analysis of No.3 Wanju-slag revealed high contents of $\mathrm{FeO}(41.92 \mathrm{wt} \%)$ and $\mathrm{SiO}_{2}(36.65$ wt\%), and other compounds including $\mathrm{Al}_{2} \mathrm{O}_{3}, \mathrm{CaO}, \mathrm{CuO}$, $\mathrm{ZnO}$ and $\mathrm{PbO}$. Metallurgical microscopy images(Figure 9) revealed white dendritic structures inside a boundary of long columnar structures. The base matrix was observed to be glassy. Table 8, Figure 10 show the SEM-EDS results for No.3 Wanju-slag. In Figure 10, 3-1 is a base matrix with an $\mathrm{Al}_{2} \mathrm{O}_{3}$ content of $7.53 \mathrm{wt} \%$ (which is lower than that in the general glassy matrix) and a $\mathrm{CaO}$ content of $17.34 \mathrm{wt} \%$

Table 5. WD-XRF results of No.2 Gyeongju-slag

\begin{tabular}{ccccccccccc}
\hline \multirow{2}{*}{ Sample } & \multicolumn{10}{c}{ Element (wt\%) } \\
\cline { 2 - 11 } & $\mathrm{FeO}$ & $\mathrm{TiO}_{2}$ & $\mathrm{SiO}_{2}$ & $\mathrm{Al}_{2} \mathrm{O}_{3}$ & $\mathrm{CaO}$ & $\mathrm{K}_{2} \mathrm{O}$ & $\mathrm{MgO}$ & $\mathrm{MnO}$ & $\mathrm{P}_{2} \mathrm{O}_{5}$ & $\mathrm{~V}_{2} \mathrm{O}_{5}$ \\
\hline No.2 & 79.08 & 0.73 & 13.05 & 5.11 & 1.06 & 0.54 & - & 0.39 & - & 0.42 \\
\hline
\end{tabular}

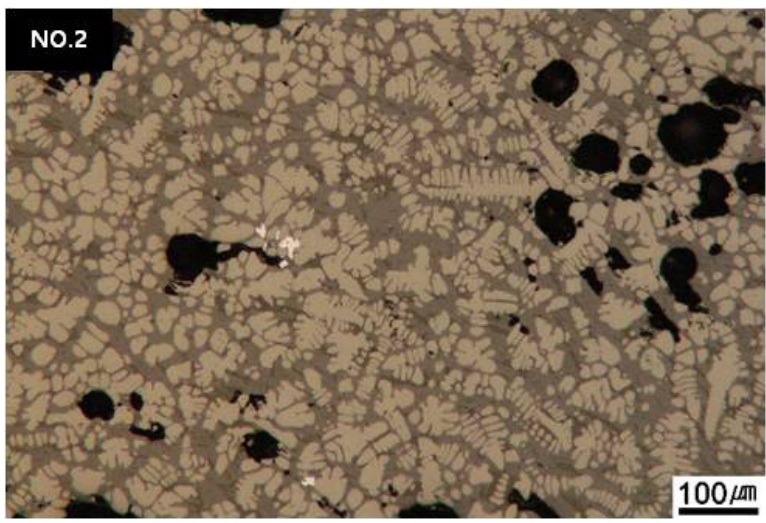

Figure 6. Microstructure of No.2 Gyeongju-slag $(\times 100)$.

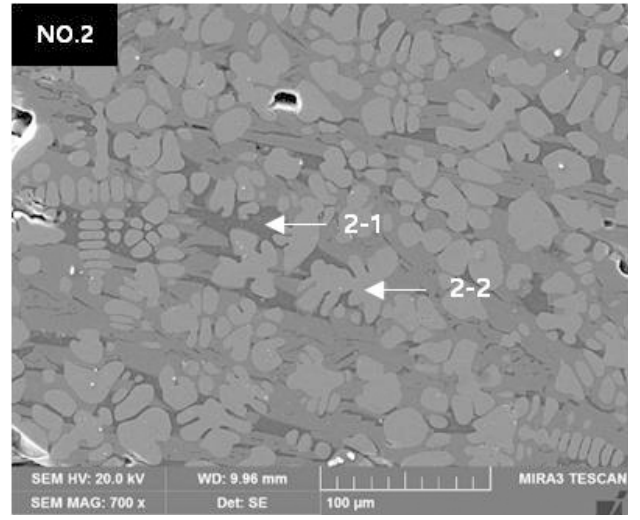

Figure 7. SEM image and points of EDS analysis of No.2 Gyeongju-slag.

Table 6. EDS results for No.2 G-slag

\begin{tabular}{|c|c|c|c|c|c|c|c|c|c|c|}
\hline \multirow{2}{*}{ Position } & \multicolumn{10}{|c|}{ Element (wt $\%)$} \\
\hline & $\mathrm{FeO}$ & $\mathrm{SiO}_{2}$ & $\mathrm{Al}_{2} \mathrm{O}_{3}$ & $\mathrm{~K}_{2} \mathrm{O}$ & $\mathrm{CaO}$ & $\mathrm{TiO}_{2}$ & $\mathrm{P}_{2} \mathrm{O}_{5}$ & $\mathrm{Na}_{2} \mathrm{O}$ & $\mathrm{MnO}$ & $\mathrm{V}_{2} \mathrm{O}_{5}$ \\
\hline $2-1$ & 51.32 & 20.81 & 12.14 & 4.62 & 6.43 & 0.81 & - & 1.14 & - & - \\
\hline $2-2$ & 98.24 & - & - & - & - & 1.76 & - & - & 0.96 & - \\
\hline
\end{tabular}


(which is higher); 3-2 is a dendritic structure of which $80.04 \mathrm{wt} \%$ is $\mathrm{FeO}$, and it is thought to be Magnetite. Raman micro spectroscope was conducted to unambiguously identify each microcrystals white in No.3 Wanju-slag. Raman shifts of $315,379,529,659,770,925$, and $1005 \mathrm{~cm}^{-1}$ were detected in the base matrix(Figure 11), which coincides
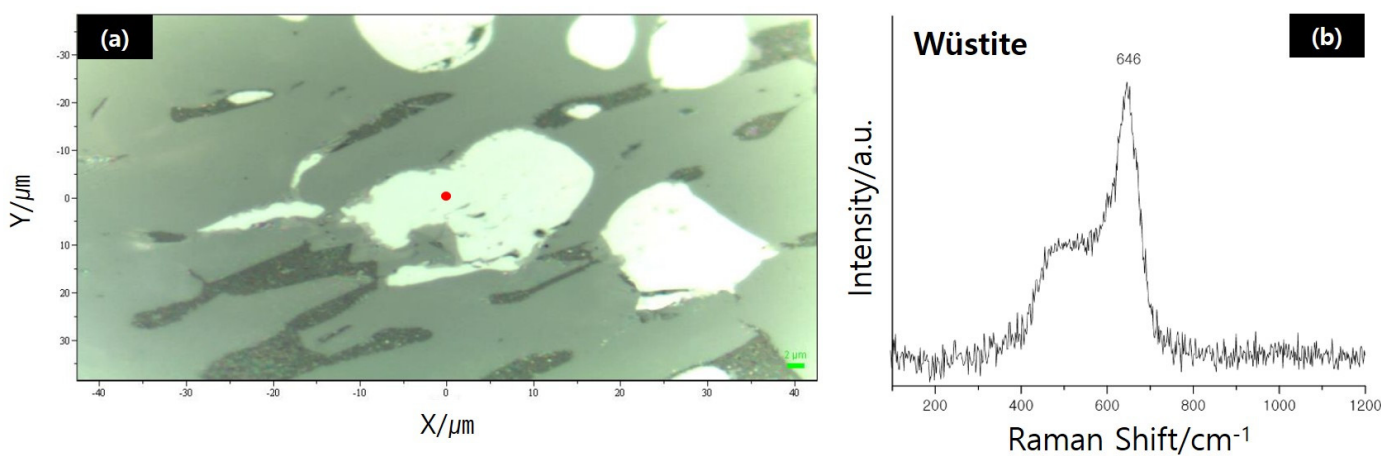

Figure 8. Raman micro spectroscopy results for No.2 Gyeongju-slag(Wüstite). (a) Image of area in which the spectrum(b) was collected.

Table 7. WD-XRF results of No.3 Wanju-slag

\begin{tabular}{cccccccccccc}
\hline \multirow{2}{*}{ Sample } & \multicolumn{10}{c}{ Element (wt\%) } \\
\cline { 2 - 27 } & $\mathrm{FeO}$ & $\mathrm{SiO}_{2}$ & $\mathrm{Al}_{2} \mathrm{O}_{3}$ & $\mathrm{CaO}$ & $\mathrm{CuO}$ & $\mathrm{ZnO}$ & $\mathrm{PbO}$ & $\mathrm{MgO}$ & $\mathrm{K}_{2} \mathrm{O}$ & $\mathrm{MnO}$ & $\mathrm{TiO}_{2}$ \\
\hline No.3 & 41.92 & 36.65 & 6.07 & 8.23 & 2.47 & 1.23 & 0.35 & 1.35 & 1.26 & 0.20 & 0.25 \\
\hline
\end{tabular}

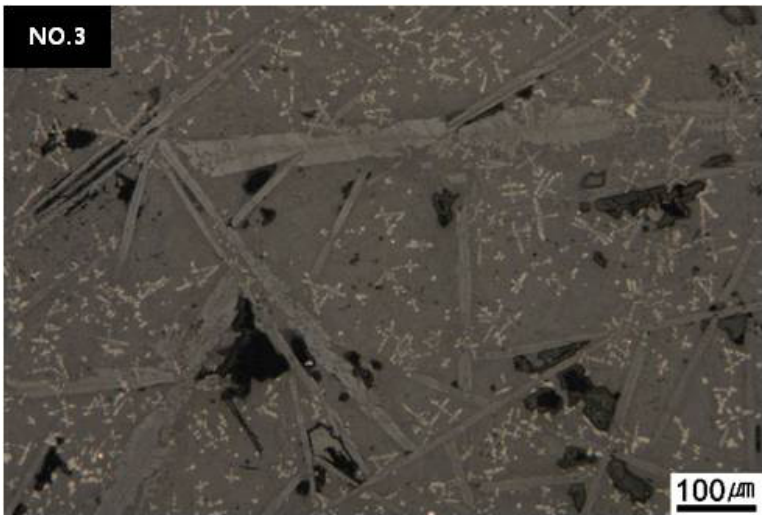

Figure 9. Microstructure of No.2 Wanju-slag $(\times 100)$.

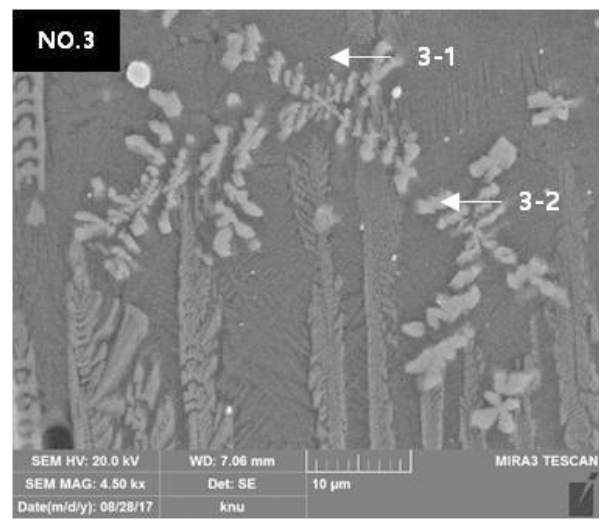

Figure 10. SEM image and points of EDS analysis of No.2 Wanju-slag.

Table 8. EDS results for No.3 Wanju-slag

\begin{tabular}{|c|c|c|c|c|c|c|c|c|c|c|}
\hline \multirow{2}{*}{ Position } & \multicolumn{10}{|c|}{ Element (wt\%) } \\
\hline & $\mathrm{MgO}$ & $\mathrm{Al}_{2} \mathrm{O}_{3}$ & $\mathrm{SiO}_{2}$ & $\mathrm{~K}_{2} \mathrm{O}$ & $\mathrm{CaO}$ & $\mathrm{FeO}$ & $\mathrm{CuO}$ & $\mathrm{ZnO}$ & $\mathrm{TiO}_{2}$ & $\mathrm{~V}_{2} \mathrm{O}_{5}$ \\
\hline $3-1$ & 1.80 & 7.53 & 39.98 & 1.06 & 17.34 & 28.99 & 0.52 & - & - & - \\
\hline $3-2$ & 0.85 & 3.92 & 7.88 & 0.33 & 2.06 & 80.04 & - & 0.70 & 0.97 & - \\
\hline
\end{tabular}


with the Raman shifts of Augite(Table 2). The white dendritic structure was identified as Magnetite via the SEM-EDS analysis. This was confirmed by Raman micro spectroscopy measurements, in which Raman shifts of 313 and $680 \mathrm{~cm}^{-1}$ were detected(Figure 12) that coincide with the Raman shifts of Magnetite(Table 2).

\section{CONCLUSIONS}

Previously reported studies on the microstructures and compounds excavated in ancient metal-production sites in country principally used XRD, SEM-EDS and XRF. However, there were many difficulties in accurately identifying the microcrystals with these methods. Therefore, in this study, microstructures of slags discharged from smelting
processes(No.1 Pohang-slag, No.2 Gyeongju-slag) and the slags excavated from the Ungyo site in Wanju, Jeollabuk-do (No.3 Wanju-slag) were clearly analyzed using Raman micro spectroscope.

White polygonal crystals in the microstructures of No.1 Pohang-slag. In previous studies, these crystals were identified as Magnetite; however, SEM-EDS results indicated a greater content of $\mathrm{TiO}_{2}$ compared to Magnetite. Raman micro spectroscopy confirmed these white polygonal crystals to be Ulvöspinel. Next, Dendritic structure in No.2 Gyeongju-slag, identification was confirmed by Raman micro spectroscopy. Lastly, No.3 Wanju-slag indicated a white dendritic structure, which was presumed to be a glassy matrix. However, SEM-EDS analysis indicated a content of oxides for this sample that differs from that of a typical glassy matrix.
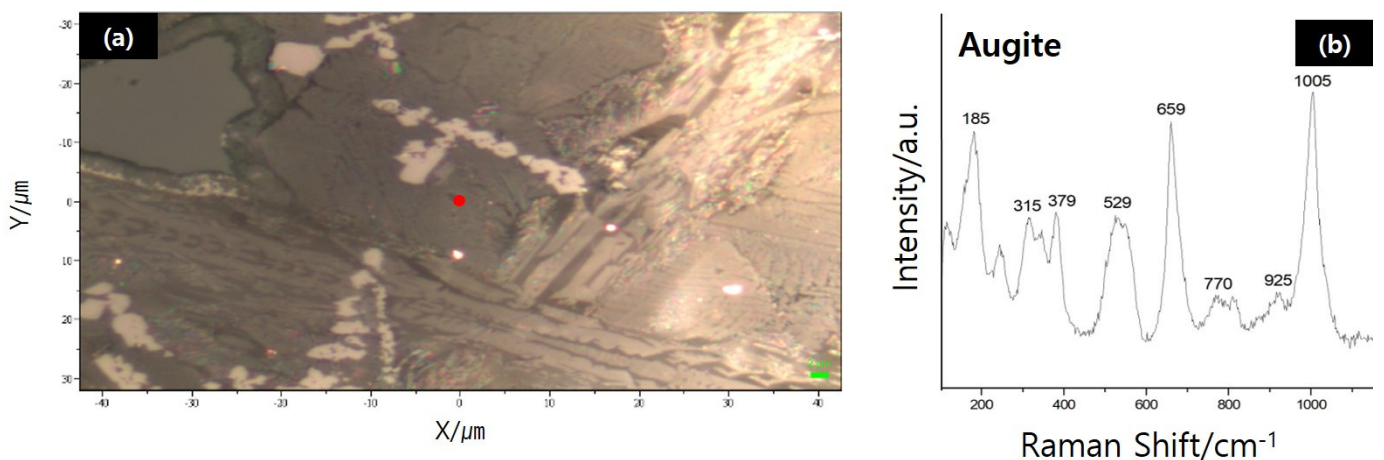

Figure 11. Raman micro spectroscopy results for No.3 Wanju-slag(Augite). (a) Image of area in which the spectrum(b) was collected.
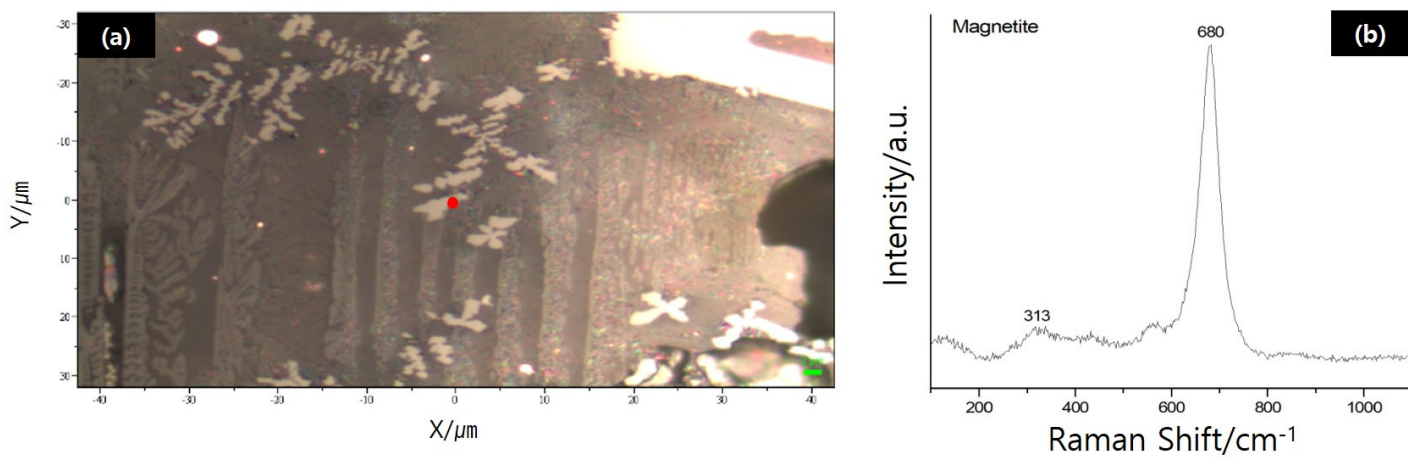

Figure 12. Raman micro spectroscopy results for No.3 Wanju-slag(Magnetite). (a) Image of area in which the spectrum(b) was collected. 
Furthermore, Raman micro spectroscopy results revealed that these structures were not glassy matrices, but Augites.

The results of this study confirm that Raman micro spectroscope can accurately identify the microcrystals of slags, which are otherwise difficult to distinguish only by their compositions and crystal morphology. Hence, this technique, which has only had limited use thus far in cultural artifact research in country, is highly promising for slag analysis. However, the present study represents only the start of a larger effort to generate reliable standard Raman shift results for slag analysis. If sufficient standard data is obtained via the on going research, Raman micro spectroscope can be widely used to identify microcrystals found in slag compounds at metal production sites, and thus the nature of these sites can be fully understood.

\section{ACKNOWLEDGEMENTS}

This work was supported by a National Research Foundation of Korea(NRF) grant funded by the Korea government(No. NRF-2016R1D1A2B03936071).

\section{REFERENCES}

Bae, C.R., 2018, Study on the iron production process through the analysis of by-products excavated from iron smelting site in Bupyeong-ri, Inje, Korea. Master thesis, Kongju National University, Gongju. (in Korean with English abstract)

Buzatu, A. and Buzgar, N., 2010, The Raman study of single-chain silicates. Analele Științifice ale Universității, Alexandru Ioan Cuza, Iași, Geologie, 108-125.

Choi, N.Y., 2017, A metallurgical study on the by-products of the bronze production in the Goryeo Dynasty as excavated from Sinpung site in Wanju, Jeollabuk-do, South Korea. Master thesis, Kongju National University, Gongju. (in Korean with English abstract)
Demoulin, A., Trigance, C., Neff, D., Foy, E., Dillmann, P. and L'Hostis, V., 2010, The evolution of the corrosion of iron in hydraulic binders analysed from 46-and-260year-old buildings. Corrosion Science, 52(10), 3168-3179.

Kang, Y.H., 2009, Metallurgical study of iron slag excavated from the centural Korean Peninsula: Focusing on Gyesil-ri in Kongju, Yeonje-ri in Chongwon and Beopcheon temple site in Wonju. Master thesis, Kongju National University, Gongju. (in Korean with English abstract)

Kim, B.J. and Jeong, G.Y., 2015, Raman spectroscopic study on corrosion layers of archaeological bronzes. Cultural Heritage, 48, 4-23. (in Korean with English abstract)

Lee, H.J., 2015, Study on the pigments analysis of the colored cultural properties by spectrometry. Master thesis, Korea National University of Cultural Heritage, Buyeo. (in Korean with English abstract)

Lee, H.Y., Park, H.H., Kim, S.J. and Yoo, J.E., 2012, Study on characteristics and features of re-corrosion on archaeological iron nails after conservation treatments. Journal of Conservation Science, 28(4), 343-351. (in Korean with English abstract)

Lee, Y.N., 2017, Metallurgical study on the by-products of the iron smelting excavated from Jinwi region in Pyeongtaek. Master thesis, Kongju National University, Gongju. (in Korean with English abstract)

Muralha, V.S.F., Rehren, T. and Clark, R.J.H., 2011, Characterization of an iron smelting slag from Zimbabwe by Raman microscopy and electron beam analysis. Journal of Raman Spectroscopy, 42(12), 2077-2084.

Park, H.H., Lee, J.S. and Yoo, J.E., 2011, Application study of Raman micro-spectroscopy for analysis on corrosion compound of iron artifacts. Conservation studies, 32, 89-98. (in Korean with English abstract)

Wang, A., Kuebler, K.E., Jolliff, B.L. and Haskin, L.A., 2004 Raman spectroscopy of Fe-Ti-Cr-oxides, case study: Martian meteorite EETA79001. American Mineralogist, 89(5-6), 665-680. 